\title{
Monodualistik Penanganan Tindak Pidana Pelecehan Seksual Perspektif Pembaharuan Hukum Acara Pidana Indonesia
}

\author{
Jaka Susila \\ IAIN Surakarta \\ Jakasusila66@gmail.com
}

\begin{abstract}
Abstrak
This research was intended to understand the mechanism of handling sexual harassment cases, the state's response to the protection of the rights of victims of sexual harassment and the basis of legal protection for victims of sexual harassment as a process in renewing criminal code procedure (KUHAP) in Indonesia. This research was a combination of library and field research, with descriptive analysis techniques. The results of this study indicated that it has not provided a deterrent effect for sexual harassers. This is an important concern for the handling of victims of sexual harassment so that it is not only a curative step, but also a preventive step.
\end{abstract}

Kata Kunci: victim, sexual harassment, renewal, Criminal Code Procedure

\section{Pendahuluan}

Tindak pidana pelecehan seksual merupakan suatu persoalan yang sangat serius dalam kehidupan bermasyarakrat, karena selain menjadi beban berat baik pisik maupun psikis oleh korban, tindak pidana pelecehan seksual ini merupakan persoalan yang membebani Negara. Sering kali kita membaca dan mendengar baik dari media cetak maupun dari media elektronik mengenai terjadinya tindak pidana pelecehan sexsual. Bahkan terjadinya tindak pidana pelecehan seksual ini tidak hanya di kota-kota besar saja yang relatif lebih maju kebudayaan dan kesadaran atau pengetahuan hukumnya, melainkan juga terjadi di pelosok-pelosok atau pedesaan yang relative masih memegang nilai tradisi dan adat istiadat setempat, terutama pada kalangan masyarakat yang ekonominya lemah (Pratiwi 2012). 
Sebagaimana kita mafhum bahwa sejak tanggal 31 Desember 1981 telah diundangkan Undang-Undang Nomor 8 Tahun 1981 yang lebih dikenal dengan Kitab Undang-Undang Hukum Acara Pidana (KUHAP). KUHAP ini merupakan salah satu produk hukum bangsa Indonesia yang mempunyai predikat "Karya Agung" dimana KUHAP sangat memperhatikan hak-hak seorang yang tersangkut tindak pidana, mulai dari proses penyelidikan, penyidikan, penuntutan, putusan pengadilan oleh hakim, hingga pelaksanaan putusan. Dalam proses peradilan pidana baik tersangka (offender) maupun korban kejahatan (victim of crime) menghendaki keadilan. Bagi offender menghendaki perkaranya diperiksa secara adil dengan mengindahkan hak-haknya serta aturan main yang telah ditentukan, namun bagi victim of crime juga menghendaki agar offender diadili dan kalau perlu dihukum seberat-beratnya, bahkan berharap adanya ganti rugi untuk memulihkan keadaan (Santoso and Zulfa 2004).

Sebuah realitas yang tidak terbantahkan bahwa kepentingan dan hak-hak offender lebih diperhatikan dan diutamakan dari pada kepentingan dan hak-hak Victim of Crime itu sendiri. Bagaimana tidak, sejak awal proses pemeriksaan hak-hak offender dilindungi, pelaku kejahatan berhak memperoleh bantuan hukum, memperoleh perlakuan yang baik, dijauhkan dari penyiksaan, diberitahukan tentang kejahatan yang disangkakan kepadanya bahkan hak untuk meminta ganti rugi manakala terjadi kekeliruan dalam proses perkara pidana, singkatnya segala hak dan atribut yang melekat pada offender sebagai manusia dikemas dalam KUHAP (Mukarramah 2015).

Adapun hak victim of crime dikemas sangat minim, bahkan tidak diakomudir oleh KUHAP, walaupun kita mengetahui bahwa, derita yang dialaminya sudah dirasakan ketika terjadinya kejahatan, saat melapor hingga mengikuti proses persidangan. Trauma akibat akan menerima perlakuan tidak menyenangkan dari lingkungannya. Hal ini berimplikasi pada enggannya victim of crime untuk melapor kejadian yang dideritanya, karena semula laporan itu bertujuan untuk mengurangi beban masalah yang dideritanya, menjadi permasalahan baru baik berupa cemooh dari masyarakat maupun dari aparatur penegak hukum yang terkadang kurang responsip dan tidak bersahabat, belum lagi karena adanya intimidasi dari offender terhadap victim of crime (Surbakti 2010).

Berbagai hasil penanganan terhadapkasus kejahatan pelecehan seksual menunjukkan bahwa sistem penegakan hukum pidana terutama untuk mencegah berbagai praktik kejahatan di bidang seksual masih lemah. Umumnya kejahatan seksual nanti terungkap ketika korban mengadu atau keluarga korban melaporkan telah terjadi pelecehan seksual. Tidak adanya upaya pencegahan dan tidak adanya hukuman yang berat, bagi pelaku pelecehan seksual menyebabkan perbuatan tersebut terus berulang. 


\section{Penanganan dan Sanksi dalam Kasus Pelecehan Seksual}

Kekerasan/pelecehan seksual dapat sangat bervariasi berupa percobaan perkosaan, perkosaan, sadisme dalam hubungan seksual, pemaksaan aktivitasaktivitas seksual lain yang tidak disukai, merendahkan, menyakiti atau melukai korban. Disebutkan lebih terperinci bahwa kejahatan di bidang kesusilaan adalahkejahatan mengenai hal yang berhubungandengan masalah seksual(Arief 2010). Di dalam KitabUndang-undang Hukum Pidana (KUHP)diatur dalam Bab XVI Buku II dengan titel"Kejahatan Terhadap Kesusilaan". Yaitu Pasal 281 s/d Pasal 297 dan Pasal 299.

Unsur-unsur yang harus dipenuhi agar suatu perbuatan dapat dianggap sebagai tindak pidana pelecehan seksual dari perumusan Pasal 81 ayat (2) Undang-Undang Nomor 23 Tahun 2002 tentang ketentuan pidana adalah:

a. Unsur Subyektif

1) Setiap orang Unsur pertama tindak pidana itu adalah perbuatan orang, pada dasarnya yang dapat melakukan tindak pidana itu manusia (natuurlijke personen). Selain manusia, ada pula badan hukum, perkumpulan atau korporasi dapat menjadi subyek tindak pidana, apabila secara khusus ditentukan dalam undang-undang untuk delik tertentu.

2) Dengan sengaja. Memorie van Toelichting (MvT) mengartikan kesengajaan sebagai menghendaki dan mengetahui (willens en wetens). Soedarto mengatakan sengaja berarti menghendaki dan mengetahui apa yang dilakukan.

b. Unsur Obyektif

Melakukan tipu muslihat, serangkaian kebohongan, atau membujuk anak untuk melakukan persetubuhan dengannya atau dengan orang lain. Tipu muslihat dijelaskan oleh Anwar adalah perbuatan-perbuatan yang dilakukan sedemikian rupa, sehingga perbuatan-perbuatan itu menimbulkan percaya atau yakin atas kebenaran, dari sesuatu kepada orang lain, sehingga tidak terdiri atas ucapan saja tetapi ada perbuatan. Membujuk dijelaskan sebagai suatu perbuatan yang dapat mempengaruhi orang lain agar kehendak orang yang dipengaruhi tersebut sama dengan kehendak yang membujuk. Membujuk dalam hal ini dilakukan dengan mengiming-imingi, lebih tepat lagi jika berhubungan dengan orang yang mudah dibujuk yaitu anak-anak yang lugu dan polos sehingga mudah mempengaruhinya.

\section{Sanksi}

Untuk sanksi yang disebutkan bagi pelaku pelecehan seksual adalah disebutkan dalam KUHP. Khusus untuk kasus pelecehan seksual terhadap anak maka dalam pasal- pasal yang mengatur tentang hukuman bagi pelaku pelecehan seksual terhadap anak di bawah umur terdapat dalam Pasal 287, dan 292 KUHP (Chazawi 2006 :75) : 
a. Pasal 287 ayat (1) KUHP berbunyi:

"Barang siapa bersetubuh dengan seorang perempuan di luar perkawinan, padahal diketahuinya atau sepatutnya harus diduganya bahwa umurnya belum lima belas tahun, atau umurnya tidak jelas, bahwa ia belum waktunya untuk dikawin, diancam dengan pidana penjara paling lama sembilan tahun". Tapi apabila perbuatan persetubuhan itu menimbulkan luka-luka atau kematian maka bagi si pelaku dijatuhkan hukuman penjara lima belas tahun, sebagai mana yang telah ditetapkan dalam Pasal 291 KUHP.

b. Pasal 292 KUHP:

“Orang dewasa yang melakukan perbuatan cabul dengan orang lain sesama kelamin, yang diketahuinya atau sepatutnya harus diduganya belum dewasa, diancam dengan pidana penjara paling lama lima tahun."

Sedangkan di dalam Undang -Undang No 23 Tahun 2002 tentang Perlindungan Anak, ada dua Pasal yang mengatur tentang ancaman hukuman bagi pelaku pelecehan seksual terhadap anak di bawah umur yaitu Pasal 81 dan Pasal 82 (Poerwandari 2010).

1) Pasal 81 yang bunyinya:

"Setiap orang yang dengan sengaja melakukan kekerasan atau ancaman kekerasan memaksa anak melakukan persetubuhan dengannya atau dengan orang lain, dipidana dengan pidana penjara paling lama 15 (lima belas) tahun dan paling singkat 3 (tiga) tahun dan denda paling banyak Rp.300. 000. 000, 00 (tiga ratus juta rupiah) dan paling sedikit Rp. 60.000.000,00 (enam puluh juta rupiah)."

2) Pasal 82 yang bunyinya:

"Setiap orang yang dengan sengaja melakukan kekerasan atau ancaman kekerasan, memaksa, melakukan tipu muslihat, serangkaian kebohongan, atau membujuk anak untuk melakukan atau membiarkan dilakukan perbuatan cabul, dipidana dengan pidana penjara paling lama 15 (lima belas) tahun dan paling singkat 3 (tiga) tahun dan denda paling banyak Rp.300. 000. 000, 00 ( tiga ratus juta rupiah) dan paling sedikit Rp. 60. 000. 000, 00 (enam puluh juta rupiah)."

Dalam praktiknya, walau UU Perlindungan Anak sudah disahkan pada tahun 2002 lalu, namun pelaksanaannya dinilai masih setengah hati. Kepolisian belum menjadikan UU Perlindungan Anak sebagai acuan dalam menangani kasus kekerasan . Kepolisian nyatanya masih menggunakan KUHP sebagai acuan, sementara KUHP tidak mengatur secara khusus tentang kekerasan seksual terhadap anak. Sementara itu, pasal dalam KUHP yang sering dipakai polisi untuk menjerat pelaku kekerasan seksual terhadap anak, yakni Pasal 287, masih dianggap belum memadai dan jauh dari rasa keadilan masyarakat.

al-ạ̣kām Vol. 4, Nomor 2, 2019 
Sedangkan bagi korban dewasa, maka ancaman untuk pelaku pelecehan seksual melalui Undang-undang No. 23 Tahun 2004 tentang PKDRT dan KUHP yang menyangkut 'perkosaan' Pasal 285 KUHP yang merupakan tindak kekerasan seksual yang sangat mengerikan dan merupakan tindakan pelanggaran hak-hak asasi yang paling kejam terhadap perempuan, juga oleh UU No. 13 Tahun 2006 khususnya dalam Pasal 5, Pasal 8, dan Pasal 9 yang merupakan hak dari seorang perempuan yang menjadi korban.

Berdasarkan uraian di atas menunjukkan bahwa sanksi hukum pada pelaku pemerkosaan atau kekerasan seksual tidak cukup dengan hanya hukuman kurungan penjara atau denda uang seperti pada pasal-pasal yang telah disebutkan di atas. Pelecehan seksual yang terjadi berdampak besar bagi korban terutama jika korbannya berjenis kelamin perempuan. Jati diri mereka akan terancam dan membuat dirinya sulit untuk berkonsentrasi baik dalam belajar maupun bekerja. Dalam hal ini pelaku telah menunjukkan tindakan-tindakan yang dapat melemahkan korban pemerkosaan atau pelecehan seksual. Oleh karenanya diperlukan suatu kajian yang dapat memberikan perlindungan bagi korban pelecehan seksual dan di sisi lain memberikan efek jera bagi pelaku pelecehan seksual.

\section{Perlindungan Korban Pelecehan Seksual}

Menurut Gosita bahwa pengertian korban adalah "orang-orang yang baik secara individual maupun kolektif telah menderita kerugian, termasuk kerugian fisik atau mental, emosional, ekonomi, atau gangguan substansial terhadap hak-haknya yang fundamental, melalui perbuatan atau kondisi yang melanggar hukum di masing-masing negara, termaksud penyalahgunaan kekuasaan" (Gosita 2014). Dalam pengertian yang diuraikan oleh Anggita bahwa korban adalah mereka yang menderita jasmaniah dan rohaniah sebagai akibat tindakan orang lain yang mencari pemenuhan kepentingan diri sendiri atau orang lain yang bertentangan dengan hak asasi pihak yang dirugikan (Mansur and Gultom 2007). Dengan demikian pengertian korban pelecehan seksual merupakan orang yang menderita jasmaniah dan rohani karena menerima akibat karena adanya pelecehan seksual.

Sebagai bagian dari perlindungan hukum bagi korban pelecehan seksual maka berdasarkan hukum positif, maka pihak korban dapat menuntut kerugian atau ganti rugi terhadap pihak terpidana. Ganti rugi adalah sesuatu yang diberikan pada pihak yang menderita atau mengalami kerugian sepadan dengan memperhitungkan kerusakan yang dideritanya. Perbedaan antara kompensasi dan juga restitusi adalah "kompensasi timbul berasal permintaan korban suatu tindak pidana, dan dibayar oleh masyarakat atau merupakan suatu bentuk pertanggungjawaban dari masyarakat atau dari negara (the responsible of the society), sedangkan restitusi lebih bersifat pada pidana, yang timbul dari putusan pengadilan terkait perkara pidana dan dibayar oleh terpidana atau merupakan wujud pertanggungjawaban dari terpidana( $C$ and $A$ 2010). 
Khususnya perlindungan hukum bagi korban pelecehan seksual maka Perlindungan korban seharusnya dapat mencakup bentuk perlindungan yang bersifat abstrak (tidak langsung) maupun yang konkret (langsung). Perlindungan yang abstrak pada dasarnya merupakan bentuk perlindungan yang hanya bisa dinikmati atau dirasakan secara emosional (psikis), seperti rasa puas (kepuasan). Perlindungan yang kongkrit pada dasarnya merupakan bentuk perlindungan yang dapat dinikmati secara nyata, seperti pemberian yang berupa atau bersifat materi maupun non-materi. Dalam sistem hukum maka pengaturan perlindungan korban pelecehan seksual dalam Hukum pidana Positif Indonesia diatur dalam:

a. Dalam Kitab Undang-Undang Hukum Pidana (KUHP)

Secara implisit, ketentuan Pasal $14 \mathrm{c}$ ayat (1) KUHP telah memberi perlindungan terhadap korban kejahatan. Pasal tersebut berbunyi:"Pada perintah yang tersebut dalam Pasal 14a kecuali dalam hal dijatuhkan pidana denda, maka bersama-sama dengan syarat umum, bahwa orang yang dipidana tak akan melakukan tindak pidana, hakim boleh mengadakan syarat khusus bahwa orang yang dipidana itu akan mengganti kerugian yang terjadi karena tindak pidana itu, semuanya atau sebagiannya saja, yang akan ditentukan pada perintah itu juga, yang kurang dari masa percobaan itu." Menurut ketentuan Pasal 14c ayat (1), begitu pula Pasal 14a dan b KUHP, hakim dapat menjatuhkan pidana dengan menetapkan syarat khusus kepada terpidana dengan maksud guna mengganti kerugian yang ditimbulkan kepada korban(Mulyadi 2014).

b. Dalam Kitab Undang-Undang Hukum Acara Pidana (KUHAP) Bab III Tentang Penggabungan Perkara Ganti Kerugian, Pasal 98 s/d 101, Korban dapat mengajukan gugatan mengenai kejahatan yang telah dialaminya sekaligus kerugian yang dideritanya.

c. Perlindungan Saksi dan Korban Di dalam UU Nomor 31 Tahun 2014ini terdapat beberapa perubahan, termasukterdapat perubahan atas Pasal 5 yang mengaturtentang hak-hak seorang saksi dan jugakorban, perubahan tersebut menjadi sebagaiberikut:

1) mendapatkan perlindungan untuk keamanan pribadi, keluarga, dan harta bendanya, serta bebas dari ancaman yang berkenaan dengan kesaksian yang akan, sedang, atau telah diberikan;

2) ikut serta di dalam proses memilih danjuga menentukan bentuk perlindunganRestitusi adalah ganti kerugian yang diberikan kepada korban atau keluarganya oleh pelaku atau pihak ketiga,dapat berupa pengambilan harta milik, pembayaran ganti kerugian untuk kehilangan atau penderitaan ataupenggantian biaya untuk tindakan tertentudan juga dukungan keamanan;

Bagi korban, Undang-Undang ini juga merupakan alat baru untuk mengakses keadilan karena memuat (Mulyadi 2014):

al-aḥkām vol. 4, Nomor 2, 2019 
1) Jaminan hukum tentang perlindungan bagi saksi, korban dan pelapor dari tuntutan secara hukum baik pidana maupun perdata atas laporan, kesaksian yang akan, sedang, atau telah diberikannya. Walaupun masih terbatas, jaminan bagi pelapor adalah penting, terutama karena masih banyak korban yang tidak berani secara sendiri melaporkan kejahatan yang menimpanya.

2) Adanya perluasan cakupan perlindungan yang dapat diperoleh oleh para saksi dan korban tindak pidana-tindak pidana yang menempatkan korban dalam situasi rentan dan berada dalam ancaman terus-menerus seperti korban-korban atau saksi pada situasi konflik, situasi perdagangan orang, situasi birokrasi dan lain sebagainya.

3) Adanya ketegasan asas-asas yang menjadi acuan implementasi dan operasional penyediaan perlindungan saksi dan korban, yaitu asas penghargaan atas harkat dan martabat manusia, rasa aman, keadilan, tidak diskriminatif, dan kepastian hukum.

4) Adanya penjabaran yang cukup rinci tentang hak-hak saksi dan korban dalam proses peradilan, yaitu:

a) memperoleh perlindungan atas keamanan pribadi, keluarga, dan harta bendanya, serta bebas dari ancaman yang berkenaan dengan kesaksian yang akan, sedang atau telah diberikan;

b) ikut serta dalam proses memilih dan menentukan bentuk perlindungan dan dukungan keamanan;

c) memberikan keterangan tanpa tekanan;

d) mendapatkan penerjemah;

e) bebas dari pertanyaan yang menjerat;

f) mendapat informasi mengenai perkembangan kasus;

g) mendapat informasi mengenai putusan pengadilan;

h) mengetahui dalam hal terpidana dibebaskan;

i) mendapat identitas baru;

j) mendapatkan tempat kediaman baru;

k) memperoleh penggantian biaya transportasi sesuai dengan kebutuhan;

I) mendapat nasihat hukum; dan atau

$\mathrm{m}$ ) memperoleh bantuan biaya hidup sementara sampai batas waktu perlindungan berakhir. (Pasal 5 ayat 1) 4) Termaktubnya Kekerasan Dalam Rumah Tangga (KDRT) sebagai jenis kasus yang berhak atas perlindungan saksi dan korban.

d. Selanjutnya dijelaskan pula pada UU No. 13 Tahun 2006 bahwa seorang korban dalam pelanggaran hak asasi manusia yang berat, selain korban berhak atas hak sebagaimana dimaksud diatas juga berhak untuk mendapatkan:. bantuan medis; dan juga bantuan 
rehabilitasi psiko-sosial. Adanya perhatian pada bantuan medis, rehabilitasi psikososial, kompensasi dan restitusi lainnya pada pelanggaran HAM berat. Bantuan ini sangat penting bagi perempuan korban kekerasan, khususnya kekerasan seksual, dalam situasi konflik dan berbagai situasi yang timbul sebagai akibat kejahatan terhadap kemanusiaan.

e. Diperkenankannya pemberian kesaksian oleh saksi dan korban tanpa kehadiran langsung di persidangan, baik melalui tulisan maupun rekaman suara. Terobosan ini sangat penting bagi korban kekerasan seksual yang seringkali masih trauma, merasa takut mengalami reviktimisasi dan juga malu yang tak tertanggungkan pada saat memberikan kesaksian.

Menurut Ketentuan Hukum Pidana di Luar KUHP dan KUHAP Perlindungan korban kejahatan dapat dilihat pula pada Undang-Undang di luar KUHP dan KUHAP. Hanya, orientasi perlindungan tersebut juga bersifat implisit dan abstrak. Tegasnya, perlindungan itu bukan imperatif, nyata, dan langsung. Undang-Undang dimaksud adalah sebagai berikut:

a. Undang-Undang Nomor 7 Tahun 1984 Tentang Ratifikasi Konvensi Penghapusan Segala

b. Bentuk Diskriminasi terhadap Perempuan;

c. Undang-Undang Nomor 39 Tahun 1999 Tentang Hak Asasi Manusia;

d. Undang-Undang Nomor 23 Tahun 2002 Tentang Perlindungan Anak;

e. Undang-Undang Nomor 23 Tahun 2004 Tentang Penghapusan Kekerasan Dalam Rumah Tangga;

f. Undang-Undang Nomor 13 Tahun 2006 Tentang Perlindungan Saksi dan Korban. Misalnya terkait dengan pelecehan seksual, ekploitasi seksual, perkosaan, pemaksaan aborsi, perkawinan, pemaksaan pelacuran, penyiksaan seksual, dan perbudakan seksual.

Dalam hal lain, bentuk perlindungan hukum bisa saja diberikan oleh Unit PPA kepada korban tindak pidana pelcehan seksual, antara lain:

a. Kerahasiaan identitas korban.

Kepolisian memberikan bentuk perlindungan terhadap anak perempuan sebagai korban tindak pidana kekerasan seksual dengan merahasiakan identitas korban dan melakukan pemeriksaan secara tertutup pada ruangan yang telah disediakan secara khusus oleh Unit PPA. Selain itu, polisi juga menjauhkan dari publikasi media, baik media elektronik maupun media massa. Hal ini dilakukan karena anak perempuan sebagai korban tindak pidana kekerasan seksual merasa malu karena kejadian yang menimpanya,karenadianggap aib yang memalukan baik bagi dirinya sendiri, keluarga maupun masyarakat.

Selain itu, korban merasa bersalah dan menganggap dirinya sudah tidak berharga lagi, kotor sehingga dia menjadi benci pada diri sendiri. Tujuan dari kerahasiaan identitas korban adalah agar anak perempuan sebagai korban tindak pidana kekerasan seksual tidak mengalami penganiayaan yang keduakalinya, yaitu pelecehan yang dilakukan oleh 
masyarakat.

b. Pemberian konseling di luar jalur hukum

Pemberian konseling yaitu konsultasi kepada korban diluar jalur hukum, ini dilakukan sebelum dilakukannya penyidikan. Pendekatan secara halus ini dilakukan dengan tujuan agar korban tidak merasa takut dan trauma setelah dilakukannya penyidikan. Dengan adanya konseling ini diharapkan anak perempuan sebagai korban tindak pidana kekerasan seksual dapat menceritakan dengan sebenarbenarnya dan sejelas-jelasnya kejadian yang dialaminya tanpa rasa takut dan tertekan. Dengan begitu polisi juga mudah untuk melakukan penyidikan. Pada saat konseling, korban diizinkan untuk didampingi oleh orang tua, pengacara, maupun LSM yang berkaitan dengan masalah perlindungan terhadap anak perempuan sebagai korban tindak pidana kekerasan seksual,

Tujuannya adalah dengan adanya orang yang dikenalnya, korban akan merasa lebih nyaman dan terlindungi, sehingga tidak merasa takut dan tertekan pada saat dilakukan konseling.

c. Melakukan upaya penyidikan

Penyidikan tindak pidana kekerasan seksual selain melakukan pemeriksaan terhadap korban, polisi juga mencari alat bukti dan saksi yang mendukung adanya peristiwa tindak pidana kekerasan seksual. Alat bukti tersebut, antara lain: visum dari korban, dan saksisaksi yang mengetahui kejadian tersebut.

Perlindungan hukum juga dilakukan secara khusus oleh Unit Pelayanan Perempuan danAnak (UPPA) melakukan beberapa upaya dalammemberikan perlindungan hukum terhadapkorban kasus pelecehan seksual.

Pada dasarnya perlindungan hukum terhadap perempuan sebagai korban tindak pidana kekerasan seksual dibutuhkan kerjasama yang saling mendukung baik polisi, pemerintah maupun masyarakat. Pada kenyataannya, saat ini berbagai pihak masih memiliki kekurangan dalam berperan memberikan perlindungan hukum bagi korban pelecehan seksual. Seringkali korban pelecehan seksual justru mengalami perlakuan tidak mengenakkan dengan mendapatkan pandangan bias. Dalam hal lain, para pihak belum memperhatikan hal yang paling penting dalam perlindungan hukum bagi perempuan korban tindak pidana kekerasan seksual adalah memikirkan masa depan, karena perlindungan korban seharusnya tidak hanya dilakukan sampai putusan selesai. Namun harus tetap berjalan sampai korban tersebut benar-benar layak dalam kehidupannya kembali, serta dapat hidup dan berkembang sesuai dengan apa yang harus diterima korban tersebut.

Terbatasnya ruang lingkup dari kekerasan seksual itu sendiri yang diatur dalam Undang-Undang Nomor 23 Tahun 2004 tentang Penghapusan Kekerasan Dalam Rumah 
Tangga, Undang-Undang Nomor 39 Tahun 1999,Undang-Undang Nomor 23 Tahun 2002 sebagaimana diubah dengan Undang--Undang Nomor 35 Tahun 2014 Tentang Perlindungan Anak, dan Undang-Undang Nomor 39 Tahun 1999 Tentang Hak Asasi Manusia. Terbatasnya ruang lingkup tindak pidana kekerasan seksual tersebut, membatasi persoalan-persoalan kekerasan seksual yang dialami secara nyata oleh korban. Salah satu aspek yang digugat atau dipertanyakan eksistensinya oleh pemerhati dan lembaga advokasi masyarakat adalah aspek yuridis (KUHP), yang dinilainya punya kelemahan mendasar, sehingga sulit diharapkan dapat diimplementasikan secara makismal guna menanggulangi dan hukum seberatberatnya pelaku perkosaan agar tidak mengulangi perbuatannya. Kitab Undang-Undang Hukum Pidana (KUHP) Indonesia, yang dijadikan acuan utama bagi kalangan praktisi hukum untuk menjaring pelaku kejahatan kekerasan seksual mengandung kekurangan secara substansial dalam hal melindungi korban kejahatan. Korban dalam sisi yuridis ini tidak mendapatkan perlindungan yang istimewa.

Oleh karenanya pada perancang KUHP yang baru telah berupaya memperjelas konsep penghukuman bagi pelaku perkosaan agar supaya pelaku pelecehan seksual tidak dihukum ringan. Konsep itu merupakan langkah maju dibandingkan keberadaan rumusan dalam pasal-pasal KUHP yang lama yang cenderung tidak bisa mengakomodasi perkembangan kehidupan bermasayarakat dan berbangsa. Kasus-kasus kejahatan kekerasan seksual yang modus operandinya kasar, keji, vulgar dan sangat menjatuhkan martabat kemanusiaan dipersamakan dengan kejahatan kesusilaan pada umumnya. Dengan demikian penanganan bagi pelecehan seksual hendaknya berpijak pada sistem hukum yang berlaku di Indonesia yang pada hukuman terberat seperti hukuman seumur hidup dan juga hukuman mati. Namun bagi pendapat yang menyatakan bahwa hukuman ini tidak cukup atas dibandingkan dampak dari kejahatan seksual yang ditimbulkan, sehingga perlu perlakuan ekstern serta bentuk-bentuk sanksi rekomendasi lainnya bagi para pelaku kejahatan seksual di sini (Waluyo 2011).

Berdasarkan analisis pada sistem hukum perlindungan bagi korban kekerasan seksual maka patut diperhatikan berdasarkan analisis data di atas bahwa perlindungan hukum terhadap korban belum sepenuhnya mengembalikan luka baik psikologis maupun fisik setelah mengalami pelecehan seksual. Hal ini menjadi seharusnya menjadi perhatian penting bagi sistem hukum untuk tidak hanya memberikan perlindungan hukum selama proses hukum namun juga mengembalikan martabat korban seperti sediakala. Sesuai dengan Teori Perlindungan Hukum bahwa perlindungan korban pelecehan seksual merupakan suatu usaha yang mengadakan situasi dan kondisi yang memungkinkan pelaksanaan hak dan kewajiban korban pelecehan seksual secara manusiawi. 


\section{Pembaharuan Hukum Acara Pidana (KUHAP) di Indonesia}

Perhatian pemerintan terhadap korban tindak pidana pelecehan seksual masih minim, hingga saat ini belum ada perangkat hukum yang khusus yang bisa mengakomodir kepentingan korban dan hak-hak korban. Saat ini penanganan kasus masih terfokus kepada pelaku tindak kejahatan, baik mengenai penyelidikan, penyidikan, penuntutan, pemeriksaan dan eksekusinya. Sementara kepentingan korban yang meliputi : kerugian materiil maupun imateriil (penderitaan fisik, trauma, psikis, dll.) belum ada perangkat hukumnya, sehingga perlu adanya pembaharuan hukum acara pidana yang bisa dijadikan paying hukum bagi hak-hak korban.

Di sudut lain, situasi tersebut membuka pemikiran perlunya menata ulang hukum acara yang dirasakan memiliki banyak kelemahan. Undang-Undang Nomor 8 Tahun 1981 tentang KUHAP sering kali didengungkan sebagai karya agung anak bangsa, tentunya tidak dapat terus-menerus menahan gerusan perubahan zaman. Beberapa aspek yang dirintis dalam KUHAP ternyata tidak memenuhi semua harapan akan perlindungan terhadap HAM, hubungan kelembagaan antar penegak hukum seperti bolak-balik perkara, dan persoalanpersoalan lain dalam implementasi KUHAP selama lebih dari 3 dasawarsa menjadi perhatian publik seperti pada Kasus Nenek Minah pencuri 3 buah Kakao di PN Purwokerto atau Kasus ITE yang dialami Prita Mulyasari dirasakan mengganggu rasa keadilan.

Persoalan undang-undang dengan dinamika masyarakat menjadi sebab perlu adanya pembaharuan undang-undang. Mengutip Logemann, tiap-tiap undang-undang sebagai bagian hukum positip, bersifat statis dan tak dapat mengikuti perkembangan kemasyarakatan (Farid 1995: 113). Hal ini dipicu oleh antara lain makin berkembangnya ilmu pengetahuan dan teknologi, berubahnya batas kewilayahan daerah, dan aktualisasi kerjasama internasional. Untuk itulah, perubahan diperlukan guna mengeliminir persoalan baru yang mucul dimana hal tersebut belum terpikirkan oleh pembentuk undang-undang.

Diskusi pembaharuan hukum acara pidana akan selalu menyentuh empat komponen sistem peradilan pidana (criminal justice system), yaitu Kepolisian, Kejaksaan, Hakim (pengadilan) dan Lembaga Pemasyarakatan. Sistem peradilan pidana menurut Mardjono Reksodiputro bertujuan untuk menanggulangi kejahatan, salah satu usaha masyarakat untuk mengendalikan terjadinya kejahatan agar berada dalam batas-batas toleransi yang dapat diterimanya (Reksodiputro 1997).

Sebagaimana halnya KUHP, keinginan perubahan Hukum Acara Pidana (UndangUndang Nomor 8 Tahun 1981) menuai pro dan kontra. Terutama diantara aparat penegak hukum dalam pembahasannya. Bahkan hal itu masih terjadi ketika kedua RUU tersebut telah diajukan oleh Pemerintah kepada DPR tanggal 11 Desember 2012 yang pada akhirnya pembahasan terhenti di akhir DPR periode 2009-2014. 
Perkembangan terakhir, Rancangan KUHAP kembali masuk dalam daftar long listProgram Legislasi Nasional (Prolegnas) 2015-2019. Pembahasan Rancangan KUHAP akan dilakukan setelah pembahasan Rancangan KUHP yang menjadi RUU Prolegnas Prioritas Tahun 2015. Namun, dengan dinamika yang ada, tidak menutup kemungkinan Rancangan KUHAP baru menjadi RUU yang akan dibahas di DPR di tahun 2015 (www.hukumonline. com/berita/baca /lt54d8993156cb3/dpr-setujui-daftar-prolegnas-dengan-catatan. Tanggal 09 Februari 2015).

Mengingat bahwa sistem hukum bagi kasus pelecehan seksual maka dapat diperhatikan bahwa terdapat beberapa rekomendasi yang harus diberikan untuk memberikan kepastian jaminan bagi masyarakat. Beberapa rekomendasi yang dapat diberikan diantaranya adalah pemberian bentuk-bentuk sanksi berdasarkan perlakuan ekstern diantaranya yang diusulkan adalah hukuman kebiri. Dimana untuk memberikan suatu efek jera maka hukuman ini harus diberlakukan. Kemudian hukuman selanjutnya yaitu hukuman menyuntikan cairan kimia. Hal ini didasarkan pada kasus kejahatan seksual khususnya pedofilia sebagaimana yang diberlakukan pada Rusia dan Korea, dimana dasar pembenar atas dijatuhkan hukumannya ini atas efek domino yang timbulkan pelaku kejahatan ini, dimana para korban akan berubah menjadi pelaku nantinya setelah mereka menjadi korban kejahatan seksual khususnya pedofilia ini.

Rekomendasi lain yang diberikan hukuman rajam yang bersumber pada syariat Islam. Rekomendasi ini diberikan diantaranya diberikan oleh Majelis Ulama Indonesia yang meminta pihak berwajib agar memberikan hukuman berat terhadap terdakwa pelaku tindak pidana seksual terhadap anak ini dengan memberikan hukuman rajam. Menurut organisasi Ulama terbesar di Indonesia ini hukuman yang diberikan kepada pelaku kejahatan seksual kepada anak ini adalah relatif ringan karena paling lama 15 tahun penjara dan paling singkat 3 (tiga) tahun penjara seperti yang tertuang dalam Undang-undang Perlindungan Anak Nomor 23 Tahun 2002 belum sepenuhnya efektif. Hal ini dapat dilihat dari kuantitas serta kualitas pelecehan seksual yang makin meningkat setiap tahun sehingga diperlukan hukuman yang memberikan efek jera kepada pelaku (Santoso 2014).

Pandangan lain memasukkan bahwa sistem hukum progresif dimana hukum progresif bertumpu pada manusia membawa konsekuensi pentingnya kreativitas. Kreativitas dalam konteks penegakan hukum selain untuk mengatasi ketertinggalan hukum, mengatasi ketimpangan hukum, juga dimaksudkan untuk membuat terobosan-terobosan hukum. Terobosan-terobosan hukum inilah yang dapat diharapkan dapat mewujudkan tujuan kemanusiaan melalui bekerjanya hukum, untuk membuat kebahagian manusia. Secara teoritik hukum dibagi menjadi dua, hukum bermakna obyektif dan hukum bermakna subyektif. Hukum obyektif ialah peraturan-peraturan yang mengatur hubungan antara sesama bermasyarakat, sedangkan hukum subyektif ialah kewenangan atau hak yang

al-ạ̣kām Vol. 4, Nomor 2, 2019 
diperoleh seseorang berdasarkan hukum obyektif. Sedangkan progresif bermakna maju, berhasrat maju dan selalu maju. Dari dua term tersebut dapat dikatakan bahwa hukum progresif ialah peraturan-peraturan yang mengatur hubungan antara sesama masyarakat yang dibuat oleh seseorang atau kelompok yang mempunyai kewenangan membuat hukum dengan landasan keinginan untuk terus maju.

Oleh karenanya pemaknaan hukum progresif dengan kalimat yaitu Pertama, hukum adalah untuk manusia dan bukan sebaliknya. Hukum tidak ada untuk dirinya melainkan untuk sesuatu yang luas, yaitu untuk harga diri manusia, kebahagiaan, kesejahteraan dan kemuliaan manusia. Kedua, hukum bukan merupakan institusi yang mutlak serta final, karena hukum selalu berada dalam proses untuk terus menjadi (law as a procces, law in making). Hukum adalah untuk rakyat bukan sebaliknya. Bila rakyat adalah untuk hukum, apapun yang dipikirkan dan dirasakan rakyat akan ditepis karena yang dibaca adalah katakata Undang-Undang(Rukmini 2006). Dengan demikian hukum progresif menempatkan korban pelecehan seksual tidak hanya sebagai subjek namun juga menempatkan manusia yang menjadi korban tidak hanya secara fisik namun juga psikologis. Dimana korban pelecehan seksual kelak memikul tanggung jawab besar, sebenarnya memang anak perlu mendapat kesempatan yang seluas-luasnya untuk melanjutkan hidupnya secara optimal baik fisik, mental, maupun sosial, dan berakhlak mulia, perlu dilakukan upaya perlindungan serta untuk mewujudkan kesejahteraan korban pelecehan seksual dengan memberikan jaminan terhadap pemenuhan hak-haknya serta adanya perlakuan tanpa diskriminasi.

\section{Kesimpulan}

Berdasarkan analisis di atas maka beberapa kesimpulan dapat ditarik yaitu sebagai berikut: Pertama, dalam penanganan kasus pelecehan seksual memiliki seperangkat hukum. Dimana untuk memuat mengenai jenis-jenis kasus pelecehan seksual sudah diatur dalam Kitab Undang-undang Hukum Pidana (KUHP) diatur dalam Bab XVI Buku II dengan titel "Kejahatan Terhadap Kesusilaan". Sedangkan untuk unsur-unsur yang harus dipenuhi agar suatu perbuatan dapat dianggap sebagai tindak pidana pelecehan seksual dari perumusan Pasal 81 ayat (2) Undang-Undang Nomor 23 Tahun 2002 tentang ketentuan pidana yang di dalamnya harus memuat mengenai unsur subyektif dan unsur obyektif. Untuk sanksi yang disebutkan bagi pelaku pelecehan seksual adalah disebutkan dalam KUHP. Khusus untuk kasus pelecehan seksual terhadap anak maka dalam pasal- pasal yang mengatur tentang hukuman bagi pelaku pelecehan seksual terhadap anak di bawah umur terdapat dalam Pasal 287, dan 292 KUHP bahwa sanksi hukum pada pelaku pemerkosaan atau kekerasan seksual tidak cukup dengan hanya hukuman kurungan penjara atau denda uang seperti pada pasal-pasal yang telah disebutkan di atas. 
Meski demikian, mengingat kasus pelecehan seksual yang makin meningkat baik secara kuantitas maupun kualitas serta dampak besar bagi korban terutama jika korbannya berjenis kelamin perempuan maka sistem hukum yang memayungi penanganan korban pelecehan seksual dianggap belum sepenuhnya memberikan efek jera bagi pelaku pelecehan seksual. Hal ini menjadi perhatian penting bagi penanganan korban pelecehan seksual sehingga tidak hanya menjadi langkah kuratif namun juga preventif dengan menekan niat pelaku pelecehan seksual.

Kedua, dalam payung hukum yang memberikan perlindungan hukum maka dapat diketahui bahwa terdapat seperangkat sistem hukum yaitu diantaranya: dalam Kitab Undang-Undang Hukum Pidana (KUHP), dalam Kitab Undang-Undang Hukum Acara Pidana (KUHAP) Bab III Tentang Penggabungan Perkara Ganti Kerugian, Undang-Undang Nomor 13 Tahun 2006 Tentang Perlindungan Saksi Dan Korban, adanya penjabaran yang cukup rinci tentang hak-hak saksi dan korban dalam proses peradilan, adanya perhatian pada bantuan medis, rehabilitasi psikososial, kompensasi dan restitusi lainnya pada pelanggaran HAM berat.

Bantuan ini sangat penting bagi perempuan korban kekerasan, khususnya kekerasan seksual, dalam situasi konflik dan berbagai situasi yang timbul sebagai akibat kejahatan terhadap kemanusiaan, dan diperkenankannya pemberian kesaksian oleh saksi dan korban tanpa kehadiran langsung di persidangan, baik melalui tulisan maupun rekaman suara. Terbatasnya ruang lingkup dari kekerasan seksual itu sendiri yang diatur dalam Undang-Undang Nomor 23 Tahun 2004 tentang Penghapusan Kekerasan Dalam Rumah Tangga, Undang-Undang Nomor 39 Tahun 1999,Undang-Undang Nomor 23 Tahun 2002 sebagaimana diubah dengan Undang--Undang Nomor 35 Tahun 2014 Tentang Perlindungan Anak, dan Undang-Undang Nomor 39 Tahun 1999 Tentang Hak Asasi Manusia. Terbatasnya ruang lingkup tindak pidana kekerasan seksual tersebut, membatasi persoalan-persoalan kekerasan seksual yang dialami secara nyata oleh korban.

Analisis di atas menunjukkan bahwa terdapat perhatian penting yang seharusnya dapat dipertimbangkan yaitu sistem perlindungan hukum yang saat ini berjalan terhadap korban belum sepenuhnya mengembalikan luka baik psikologis maupun fisik setelah mengalami pelecehan seksual. Hal ini menjadi seharusnya menjadi perhatian penting bagi sistem hukum untuk tidak hanya memberikan perlindungan hukum selama proses hukum namun juga mengembalikan martabat korban seperti sediakala.

Ketiga, mengingat belum berimbangnya sistem hukum bagi korban pelecehan seksual seperti analisis sebelumnya maka muncullah beberapa rekomendasi yang dapat diusulkan. Diantaranya adalah pemebrikan Bentuk-bentuk sanksi berdasarkan perlakuan ekstern diantaranya yang diusulkan adalah hukuman kebiri serta hukuman rajam. Dimana untuk memberikan suatu efek jera maka hukuman ini harus diberlakukan. Pandangan lain 
memasukkan bahwa sistem hukum progresif dimana dalam pandangan ini maka hukum progresif menempatkan korban pelecehan seksual tidak hanya sebagai subjek namun juga menempatkan manusia yang menjadi korban tidak hanya secara fisik namun juga psikologis.

\section{Daftar Pustaka}

Arief, Barda Nawawi. 2010. Bunga Rampai Kebijakan Hukum Pidana. Jakarta: Kencana.

C, Dowden, and Andrews D A. 2010. "Effective Correctional Treatment and Violent ReOffending: A Meta-Analysis." Canadian Journal of Criminology 42, 449-76.

Gosita, Arif. 2014. Masalah Korban Kejahatan. Jakarta: PT Bhuana Ilmu Populer.

Mansur, Dikdik M. Arief, and Elisatris Gultom. 2007. Korban Kejahatan : Antara Norma Dan Realita. Jakarta: Raja Grafindo Persada.

Mukarramah, Ema. 2015. Menggugah Komitmen Negara Terhadap Perlindungan Perempuan Korban Kekerasan: Himpunan Naskah Usulan Terhadap Rancangan Peraturan Perundangundangan Dan Kajian Implementasi Kebijakan. Jakarta: Komnas Perempuan.

Mulyadi, Lilik. 2014. Kapita Selekta Hukum Pidana Kriminologi Dan Viktimologi. Jakarta: Djambatan.

Poerwandari, Kristi. 2010. Kekerasan Terhadap Perempuan: Tinjauan Psikologi Dan Feministik. Bandung: Alumni.

Pratiwi, Agust. 2012. "Integritas Perlindungan Hak-Hak Perempuan Dalam Reformasi Hukum." Perempuan Dan Hukum, 34.

Reksodiputro, Mardjono. 1997. Kriminologi Dan Sistem Peradilan Pidana. Jakarta: Pusat Pelayanan Keadilan dan Pengabdian Hukum d/h Lembaga Kriminologi Universitas Indonesia.

Rukmini, Mien. 2006. Aspek Hukum Pidana Dan Kriminologi. Bandung: PT Alumni.

Santoso, Topo. 2014. Membumikan Hukum Pidana Islam. Jakarta: Gema Insani Press.

Santoso, Topo, and Eva Achjani Zulfa. 2004. Kriminologi. Jakarta: PT. Raja Grafindo Persada.

Surbakti, Natangsa. 2010. Filsafat Hukum Perkembangan Pemikiran Dan Relevansinya Dengan Reformasi Hukum Indonesia. Surakarta: Universitas Muhammadiyah Surakarta.

Waluyo, Bambang. 2011. Viktimologi Perlindungan Korban \& Saksi. Jakarta: Sinar Grafika. 